\title{
Anticancer bioactive peptide suppresses human gastric cancer growth through modulation of apoptosis and the cell cycle
}

\author{
LIYA SU ${ }^{1,2}$, GUIHUA XU ${ }^{2}$, JIE SHEN $^{2}$, YA TUO $^{3}$, XINGGUANG ZHANG $^{4}$, \\ SHUQIN JIA $^{2}$, ZHONG CHEN ${ }^{5}$ and XIULAN SU ${ }^{1,2}$
}

\begin{abstract}
${ }^{1}$ Department of Cell Biology, Capital Medical University, Beijing; ${ }^{2}$ Clinical Medicine Research Center, Inner Mongolia Medical College and ${ }^{3}$ Department of Preventive Medicine, Inner Mongolia Medical College, Huhhot; ${ }^{4}$ Laboratory Testing Center, Inner Mongolia Medical College Affiliated Hospital, Huhhot, Inner Mongolia, P.R. China; ${ }^{5}$ Tumor Biology Section, Head and Neck Surgery Branch, National Institute on Deafness and Other Communication Disorders, NIH, Bethesda, MD, USA
\end{abstract}

Received August 4, 2009; Accepted September 15, 2009

DOI: $10.3892 /$ or_00000599

\begin{abstract}
Anticancer bioactive peptide (ACBP) was extracted from goat spleens with immunization by human gastric cancer extracts. ACBP was biochemically purified and identified as $\sim 8,000$ Da peptide. Here we report that ACBP significantly inhibited the growth of human gastric cancer line BGC-823 in vitro in a dose-dependent manner. ACBP induced BGC-823 cell apoptosis was observed morphologically both by light microscopy and electronic microscopy; and ACBPinduced apoptosis and $\mathrm{G}_{0} / \mathrm{G}_{1}$ cell cycle arrest were quantified by Annexin V-FITC/PI staining and flow cytometry. At the molecular level, ACBP induced $p 16^{\text {Ink4 }}, p 21^{\text {Wafl }}, p 27^{\text {Kipl }}$, and bax tumor suppressor and apoptotic gene expression, as well as inhibited cyclin D1, c-myc, and bcl-2 gene expression that promote tumorigenesis. In vivo, ACBP dramatically inhibited human gastric tumor growth in a xenograft model with no apparent cytotoxicity to host. Our study suggests that ACBP could be a powerful anticancer biological product through induction of cell apoptosis and cell cycle arrest.
\end{abstract}

\section{Introduction}

Gastric cancer currently ranks second in cancer mortality worldwide, with an especially high rate in Asia (1). In China, annual mortality is estimated to be as high as 16 per 100,000 population with gastric cancer accounting for the leading cause of death among malignant tumors (2). Due to distinct

Correspondence to: Dr Xiulan Su, Huhhot No. 1 Tongdao North Street, Huhhot, Inner Mongolia, 010050, P.R. China

E-mail: xlsu@hotmail.com

Dr Zhong Chen, Head and Neck Surgery Branch, NIDCD/NIH, 10/5D55, MSC-1419, Bethesda, MD, USA

E-mail: chenz@nidcd.nih.gov

Key words: bioactive peptide, gastric cancer, tumor growth, apoptosis, cell cycle discrepancies in diagnosis, prognosis, and treatment efficacy for gastric cancer patients with the same pathological staging, the traditional choice of surgery combined with palliative chemotherapy has not reached expected clinical efficacy. Development of novel therapeutic strategy is urgently required for the treatment of patients with advanced gastric cancer.

A broad spectrum of bioactive peptides exist in natural resources that involve different biological processes exhibiting regulatory activities. The identification of bioactive peptides with anticancer activity could be a new strategy to develop a novel anticancer therapeutic agent with low toxicity. Bioactive peptides refer to peptides with vital physiological effects, from either endogenous (from the host itself) or exogenous sources (from other hosts or natural products). Due to their effective absorption or delivery mechanisms, bioactive peptides exhibit more significant physiological functions than free amino acids. In addition, due to the nature of biological products, minimal toxicity would be expected for bioactive peptides when compared with classical chemotherapies or targeted therapy using small molecules. Alternatively, bioactive peptides could be used as new adjuvant agents to enhance chemotherapeutic efficacy and reduce toxicity in the treatment of cancer patients.

Anticancer bioactive peptide (ACBP) was identified from goat spleen extract after immunization with gastric cancer lysates in our laboratory. ACBP is a polypeptide with low molecular weight $(\sim 8,000 \mathrm{Da})$, which was enriched and purified by centrifugation, and microcolumn high-performance liquid chromatography (MHPLC) separation and purification. We previously observed that ACBP exhibited potent anti-neoplastic effect on mouse model with leukemia in vivo, as well as anticancer effects against human nasopharyngeal carcinoma in vitro (3-5). In addition, ACBP markedly inhibited tumor growth with few toxicity effects in long-term animal experiments $(6,7)$. However, the molecular mechanisms of ACBP anticancer effects are not yet well understood.

Here we show the potent anticancer effects of ACBP against gastric cancer cell line BGC-823 in vitro through inhibition of cell proliferation. Such effect is mediated through the induction of cell apoptosis and cell cycle $G_{0} / G_{1}$ arrest. 
ACBP modulates several important gene expressions involved in cell growth and apoptosis. The inhibitory effect of ACBP on gastric cancer growth in vivo with minimal toxicity suggests that it could be a potential therapeutic agent that warrants further clinical investigation.

\section{Materials and methods}

Production and purification of $A C B P$. ACBP was produced and extracted using the following steps. Goats were immunized five times through a series of injections with human gastric cancer extracts. The spleens were harvested from the immunized animals and frozen and thawed three times. After centrifugation at 4,000 rpm for $10 \mathrm{~min}$, the supernatants were collected and ACBP was isolated through MHPLC. Molecular weight of ACBP is 8,000 Da based on measurement with SDS-PAGE gels (Fig. 1A). Anticancer bioactive peptide (ACBP) was an invention patent of our laboratory, protected by the Chinese National Patent Bureau, patent number: ZL961222236.0.

Cell culture. Gastric adenocarcinoma cell line BGC-823 was kindly provided by Professor Ke Yang (Beijing University, Health Center, Beijing, China). Cells were maintained in RPMI-1640 culture medium (Invitrogen, USA), which was supplemented with $10 \%$ heat-inactivated fetal bovine serum (FBS, TBD Science, China), $100 \mathrm{U} / \mathrm{ml}$ penicillin, and $100 \mathrm{U} / \mathrm{ml}$ streptomycin, and cultured in a humidified atmosphere of $5 \% \mathrm{CO}_{2}$ at $37^{\circ} \mathrm{C}$.

MTT assay. Cell proliferation was measured by MTT assay [3-(4,5-dimethylthiazol-2-yl)-2,5-diphenyltetrazolium bromide, TBD Science Co., China]. MTT was dissolved in sterile PBS at $5 \mathrm{mg} / \mathrm{ml}$ at room temperature, sterilized by passing through a $0.22 \mu \mathrm{m}$ filter, and stored in the dark at $4^{\circ} \mathrm{C}$. BGC-823 human gastric cells $\left(5 \times 10^{3} /\right.$ well) were placed in $200 \mu 1$ of culture medium and incubated overnight. After $24 \mathrm{~h}$, cultures were treated with $10,15,20$ and $25 \mu \mathrm{g} / \mathrm{ml}$ of ACBP in triplicates. MTT reagent $(20 \mu \mathrm{l})$ was added at different time points and then incubated at $37^{\circ} \mathrm{C}$ for $4 \mathrm{~h}$. Following vibrating on a shaker for $10 \mathrm{~min}$, the plates were measured for absorbance at $490 \mathrm{~nm}$ wavelength using a microtiter plate reader. The inhibiting rate (IR) of cell growth was expressed as (A-B)/Ax100\% (A, the absorbance values of controls groups; $\mathrm{B}$, the absorbance values of experimental cells).

Haematoxylin-eosin staining. Cells were plated on sterile microscope coverslips to allow cell adhesion. After $24 \mathrm{~h}$, cells were treated with 20 or $25 \mu \mathrm{g} / \mathrm{ml}$ ACBP. Cultured cells were sequentially taken out of the incubator at 24 , 48 and $72 \mathrm{~h}$, and washed with cold phosphate-buffered saline (PBS) for 3 times. Cells were fixed with glacial acetic acid and methanol at 1:3 ratio for $30 \mathrm{~min}$, and stained by haematoxylin-eosin. Cell morphology was observed under a light microscope (Olympus, Tokyo, Japan).

Transmission electron microscope. BGC-823 cells were cultured in RPMI-1640 medium containing $15 \mu \mathrm{g} / \mathrm{ml}$ of ACBP for 48 h. All cells were fixed in $3 \%$ glutaraldehyde and $2 \%$ paraformaldehyde in $0.1 \mathrm{M}$ cacodylate buffer ( $\mathrm{pH} 7.4$ ) at $4^{\circ} \mathrm{C}$ for $1 \mathrm{~h}$, and then postfixed in $1 \%$ osmium tetroxice in the same buffer at $4^{\circ} \mathrm{C}$ for $1 \mathrm{~h}$. After en bloc staining with $4 \%$ tannic acid and $0.5 \%$ uranyl acetate, the samples were dehydrated in graded concentrations of ethanol. The ultrathin sections were stained with uranyl acetate and lead citrate and examined with a JEM-1200EX transmission electron microscope (JEOL Co., USA) operated at $75 \mathrm{KV}$.

Apoptosis detection by staining with Annexin V-fluorescein isothiocyanate (FITC)/propidium iodide (PI). Cells were grown on $60-\mathrm{mm}$ dishes and serum was deprived at exponential growth phase. ACBP was administrated for 24,48 and $72 \mathrm{~h}(5$ and $20 \mu \mathrm{g} / \mathrm{ml})$. Then cells were harvested at different time points and stained with Annexin V-fluorescein isothiocyanate (FITC)/propidium iodide (PI) for detection of apoptosis. The stained cells were examined using a FACSCalibur flow cytometry and data were analyzed by CellQuest software (Becton-Dickinson, CA, USA).

Cell cycle analysis. Cells were treated with $20 \mu \mathrm{g} / \mathrm{ml}$ ACBP and harvested 24, 48 or $72 \mathrm{~h}$ post treatment. Cells were incubated with $2 \mathrm{mg} / \mathrm{ml}$ RNase in PBS $(200 \mu \mathrm{l})$ and $0.1 \mathrm{mg} / \mathrm{ml}$ propidium iodide (PI) in $0.6 \%$ Nonidet $\mathrm{P}-40$ in PBS $(200 \mu 1)$ on ice for $30 \mathrm{~min}$. Cell cycle was examined using a FACSCalibur flow cytometry and data were analyzed using CellQuest software (Becton-Dickinson).

Total RNA extraction and RT-PCR. BGC-823 cells were treated with $25 \mu \mathrm{g} / \mathrm{ml}$ ACBP for 24,48 and $72 \mathrm{~h}$, and total RNA was extracted from cells using TRIzol reagent (Invitrogen, USA) according to the manufacturer's protocol. The quality and concentrations of RNA were measured by a Du-70 UV spectrophotometer (Beckman, USA). Reverse transcription was performed using an RNA PCR Kit (AMV) Version 3.0 (Takara Co., Japan), and the reaction mixture contained: $2 \mu 1$ RNA sample $(1 \mu \mathrm{g} / \mu \mathrm{l}), 2 \mu \mathrm{l} 10 \mathrm{X}$ buffer, $2 \mu \mathrm{l}$ dNTP $(1 \mathrm{mmol} / \mathrm{l}), 1 \mu \mathrm{l}$ oligo-dT primer $(0.125 \mu \mathrm{M})$, AMV RTase $20 \mathrm{U}$, RNase inhibitor $10 \mathrm{U}$ and DEPC $\mathrm{ddH}_{2} \mathrm{O}$ up to $20 \mu 1$. The mixture was kept at room temperature for $10 \mathrm{~min}$, then, was incubated at $42^{\circ} \mathrm{C}$ for $30 \mathrm{~min}$ and at $95^{\circ} \mathrm{C}$ for $15 \mathrm{~min}$. Reactions were stopped by cooling at $5^{\circ} \mathrm{C}$ for $5 \mathrm{~min}$.

PCR was performed in $50 \mu 1$ reaction mixture consisted of $10 \mu 1$ reverse transcription products, $10 \mu 15 \mathrm{X}$ buffer, $0.5 \mu 1$ each gene specific primers (20 pmol/l), $1 \mu 110 \mathrm{mM}$ dNTP, 1.5U Taq DNA polymerase (Takara), with $\mathrm{ddH}_{2} \mathrm{O}$ added up to $50 \mu \mathrm{l}$. PCR cycle parameters were conducted with a preamplification denaturation at $94^{\circ} \mathrm{C}$ for $5 \mathrm{~min}$, followed by 35 cycles of denaturation at $94^{\circ} \mathrm{C}$ for $30 \mathrm{sec}$, annealing at $58-65^{\circ} \mathrm{C}$ for $30 \mathrm{sec}$, and extension at $72^{\circ} \mathrm{C}$ for $1.5 \mathrm{~min}$, with a final extension at $72^{\circ} \mathrm{C}$ for $5 \mathrm{~min}$. $\beta$-actin was used as an internal control. Amplified PCR products were visualized in a $2 \%$ agarose gel electrophoresis containing ethidium bromide. Ratios amplified gene/ß-actin was calculated by software Imagetool 2.0 (University of Texas Health Science Center, San Antonio, TX, USA). PCR results were confirmed by three repeat amplifications. The sequences of PCR primers were designed using GenBank database and the BLAST 
A

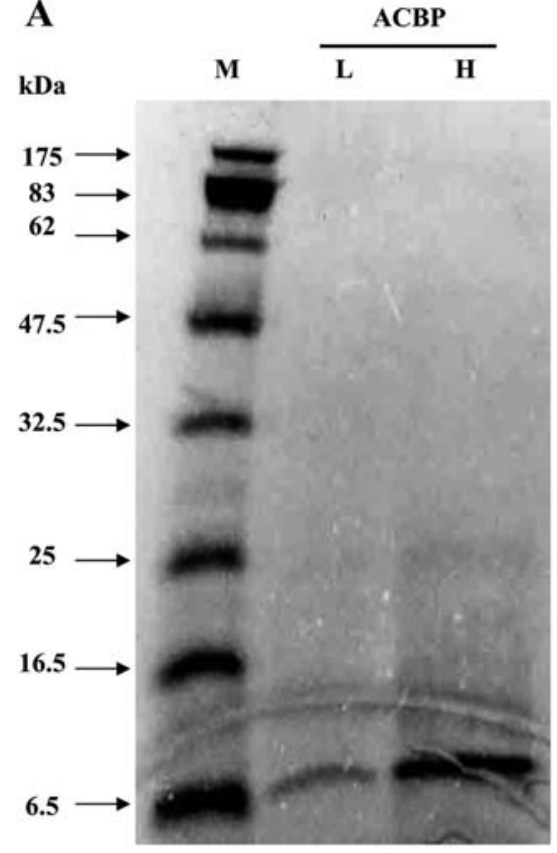

B

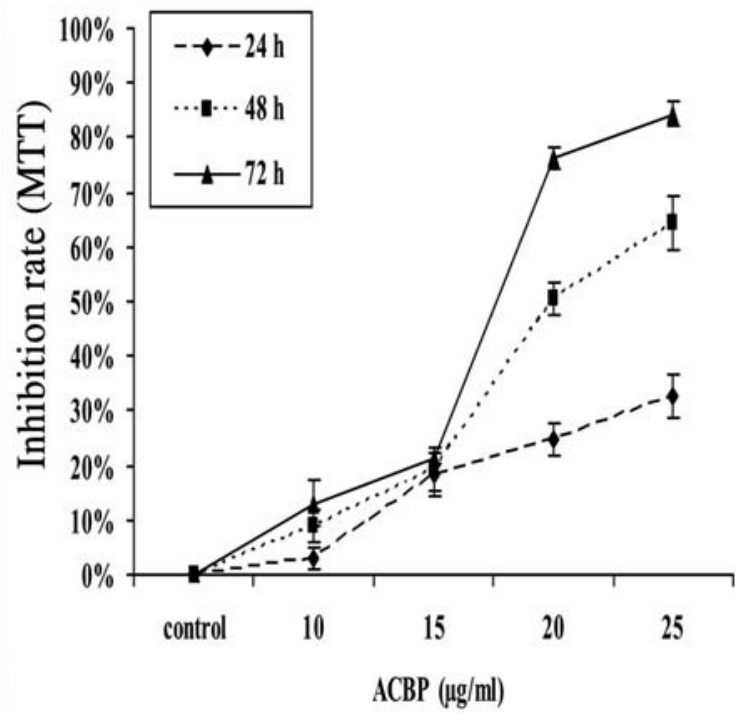

Figure 1. Molecular and biological characteristics of ACBP. (A) Purified ACBP was run on 12\% SDS-PAGE gels, and the molecular weight is 8,000 Da. M, marker; L, low concentration of ACBP $(1 \mu \mathrm{g} / \mu 1)$; H, high concentration of ACBP $(2.5 \mu \mathrm{g} / \mu 1)$. (B) ACBP suppressed BGC-823 gastric cancer cell proliferation in a time- and dose-dependent manner by MTT assay; the median concentration $\left(\mathrm{IC}_{50}\right)$ is $17.86 \mu \mathrm{g} / \mathrm{ml}$.

program. All primers were synthesized commercially by Takara Co.

Xenograft tumor model and administration of ACBP. Fiveweek-old athymic nude female mice (BALB/c nu/nu, Institute of Laboratory Animal Sciences, Chinese Academy of Medical Sciences, Beijing, China) were housed in a sterile animal facility and inoculated with BGC-823 cells $\left(5 \times 10^{6}\right)$ in $0.1 \mathrm{ml}$ of PBS subcutaneously. All mice developed single palpable tumors at day 3 , following inoculation, and were randomized into control $(\mathrm{n}=10)$ and ACBP treated group $(\mathrm{n}=10)$. ACBP $(7 \mu \mathrm{g})$ in $0.2 \mathrm{ml}$ was injected via mouse tail vein, once every other day during a 2 -week period and the control mice were injected with $0.2 \mathrm{ml}$ of sterile PBS. Tumors were measured, and the animals bearing big tumors were followed for any signs of discomfort. After two weeks, mice were sacrificed, tumors were dissected, fixed in formalin, and embedded in paraffin. Sections were stained with hematoxylin and eosin. The experiments, and animal care were conducted according to the Institutional ethics guidelines.

Immunohistochemistry. Isolated tumors were immediately fixed with $4 \%$ paraformaldehyde, embedded in paraffin, and sectioned at a thickness of $4 \mu \mathrm{m}$. PCNA protein expression in tissue was detected using SABC immonohistochemical method. After deparaffin, antigen retrieval was carried out in a microwave oven for $10 \mathrm{~min}$. A rabbit anti-human PCNA polyclonal antibody was used at 1:100 dilution. Sections were stained with 3,3-diaminobenzidine (DAB), counterstained with haematoxylin, and dehydrated in xylene, and mounted. The immunohistochemical staining was observed under light microscope (Olympus).

Statistical analysis. Data are presented as the mean \pm standard deviation (SD). Statistical analysis was performed using t-test for two groups, and two-way ANOVA for multiple comparisons; $\mathrm{p}<0.05$ was considered statistically significant. All statistical analyses were performed using the SPSS program (version 13.0).

\section{Results}

$A C B P$ inhibited proliferation of cultured BGC-823 cancer cells. To determine the effect of ACBP on cell growth, BGC823 cancer cells were treated with increasing concentrations of ACBP for 24, 48 and $72 \mathrm{~h}$, and cell survival was assessed by MTT assay (Fig. 1B). As shown, ACBP (10.0-25.0 $\mu \mathrm{g} / \mathrm{ml})$ treatment resulted in a concentration-dependent inhibition of cell proliferation. The survival of BGC-823 cancer cells was decreased by $\sim 2.9,18.2,24.6$ and $32.8 \%$ on a $24-\mathrm{h}$ exposure to $10,15,20$, or $25 \mu \mathrm{g} / \mathrm{ml} \mathrm{ACBP}$, respectively (Fig. 1B). The median concentration $\left(\mathrm{IC}_{50}\right)$ was $17.86 \mu \mathrm{g} / \mathrm{ml}$. In addition, ACBP anti-proliferative effect on BGC-823 cells was persistent and increased with prolonged treating time. For example, a 48-h treatment of BGC-823 cancer cell with the $25 \mu \mathrm{g} / \mathrm{ml}$ concentration of ACBP resulted in a $64.5 \%$ decrease in cell viability, compared to a $32.8 \%$ decrease with 24-h exposure to the same concentration of ACBP (Fig. 1B).

ACBP induces cell apoptosis observed by light and electronic microscopies. The effect of ACBP on cell proliferation was further investigated, the ACBP induced significant morphological alteration of BGC-823 cancer cell (Fig. 2A). The control cells showed the characteristics of cancer morphology with irregularly multilateral shape, conspicuous karyosomes, and plentiful cytoplasm fraction. After treatment of ACBP for $48 \mathrm{~h}$, the numbers of dividing cells were reduced significantly and a nucleus condensation and a low ratio of nucleus to cytoplasm were observed. In addition, 
A

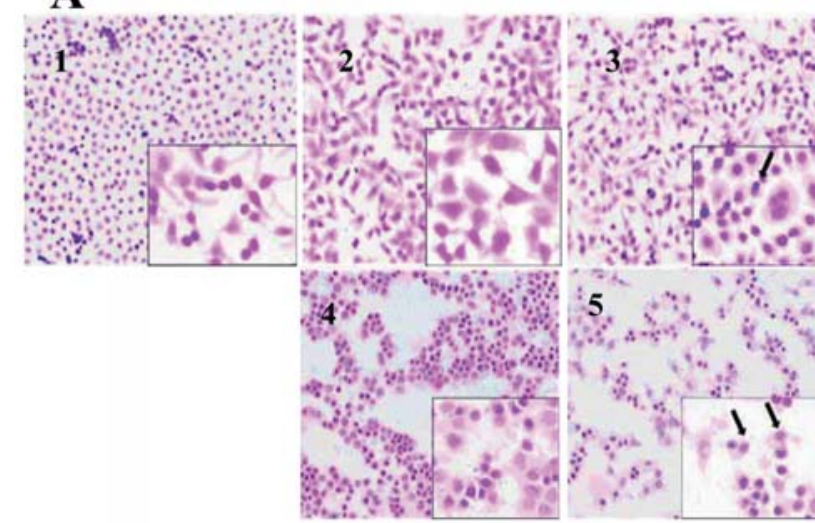

C
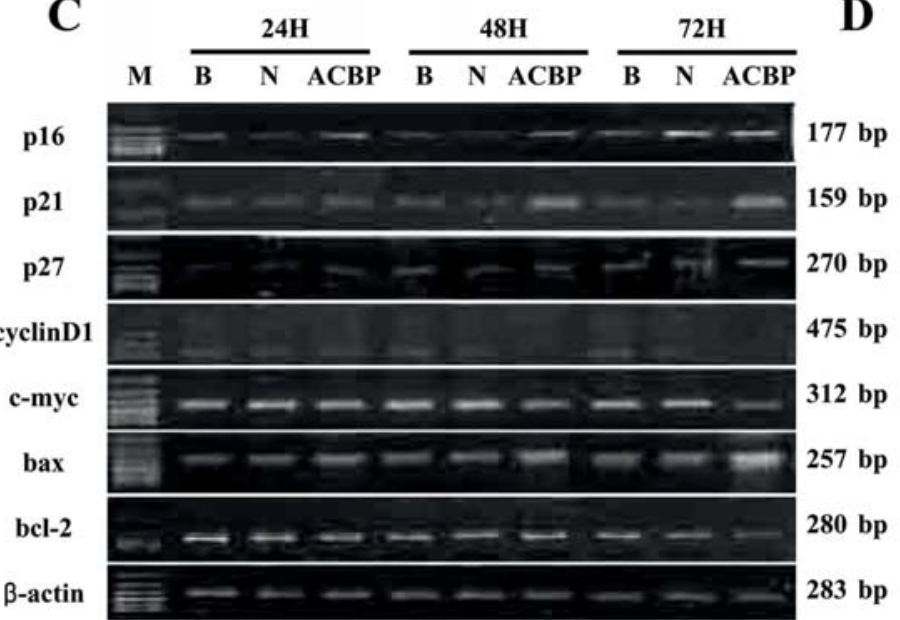

B

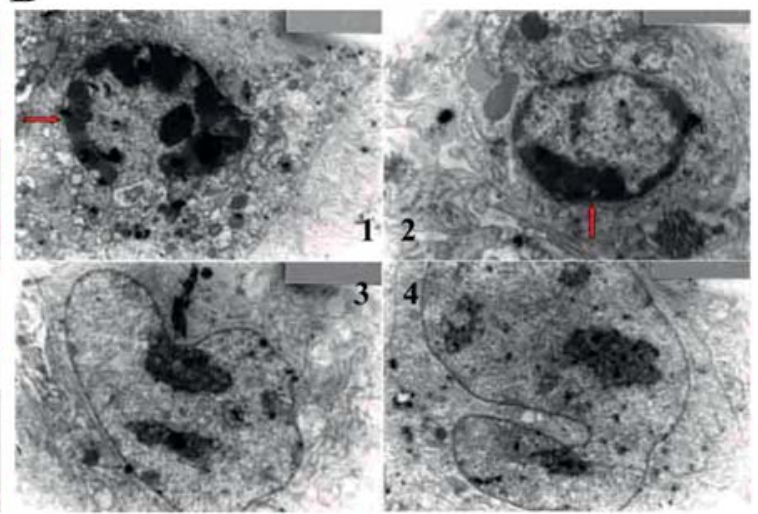

D

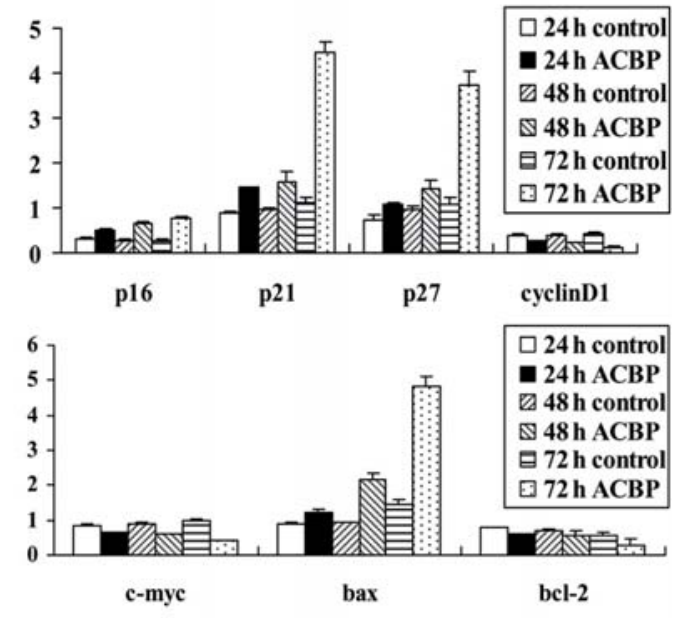

Figure 2. ACBP induced apoptosis and modulated gene expression of BGC-823 cells in vitro. (A) Morphological changes of BGC-823 cells observed after $\mathrm{H} \& \mathrm{E}$ stain under light microscopy. Blank control (1); $20 \mu \mathrm{g} / \mathrm{ml} \mathrm{ACBP}$ for $48 \mathrm{~h}(2) ; 25 \mu \mathrm{g} / \mathrm{ml} \mathrm{ACBP}$ for $48 \mathrm{~h}(3) ; 20 \mu \mathrm{g} / \mathrm{ml} \mathrm{ACBP}$ for $72 \mathrm{~h}(4) ; 25 \mu \mathrm{g} / \mathrm{ml}$ ACBP for $72 \mathrm{~h}$ (5). Nuclear condensation, apoptotic features with nucleus fragments or dissolution is highlighted by arrows. (B) Morphological alteration of BGC-823 cells treated with $20 \mu \mathrm{g} / \mathrm{ml}$ ACBP were observed under transmission electron microscope (x9000). Marked condensation of nuclear chromatin near the periphery (arrow heads) at late stage of apoptosis in the BGC-823 cells (1 and 2), in contrast to the high karyoplasmic ratio and the normal irregular shape of nuclei in control cells (3 and 4). (C) ACBP modulates gene expression of BGC-823 cells. BGC-823 cells were treated with $25 \mu \mathrm{g} / \mathrm{ml}$ of ACBP and total RNAs were harvested at the time indicated. RT-PCR products were run on $2 \%$ agarose gel, and the representative gel images are shown with the indicated molecular weight. M, marker; B, blank control; N, cells treated with normal peptide; ACBP, cells treated with ACBP. (D) The proapoptotic gene bax was increased at 48 and $72 \mathrm{~h}$, while the anti-apoptotic gene $b c l-2$ was decreased at $72 \mathrm{~h}$ after treatment.

cellular volume was deflated distinctly and cells became round in shape. After treatment of $72 \mathrm{~h}$, more apoptotic features with nucleus fragments, dissolution, or agglomeration (arrow) were observed (Fig. 2A).

ACBP-induced cell apoptosis was further demonstrated by electron microscopy, showing the characteristic apoptotic patterns in a greater number of BGC- 823 cancer cells treated with $20 \mu \mathrm{g} / \mathrm{ml} \mathrm{ACBP}$ for $48 \mathrm{~h}$ (Fig. 2B). Ultrastructural apoptotic features in the nucleus and cytoplasm of the BGC823 cancer cells were observed with irregular or fragmented shape nuclei. Chromatin was partially disrupted by the presence of nuclear vacuoles and part of chromatin appeared condensed near the periphery, close to the nuclear envelope in one or several large and homogeneous masses (Fig. 2B).

ACBP induces early apoptosis and cell cycle arrest measured by Annexin V-FITC/PI staining and flow cytometry. ACBP-induced early apoptosis of BGC-823 cells was further quantified by Annexin V-FITC/PI staining and flow cytometry. The apoptosis rate was enhanced with increased doses of ACBP, from 5 to $15 \mu \mathrm{g} / \mathrm{ml}$, and increased treatment time from 24-48 h (Table I, upper part). Persistent apoptosis was observed at both the 24 - and 48 -h time points, and optimal apoptosis $(0.59 \%)$ was observed when cells were treated with $15 \mu \mathrm{g} / \mathrm{ml} \mathrm{ACBP}$ at $48 \mathrm{~h}$, compared with the control $(0.40 \%)$. We further determined the ACBP effect on cell cycle distribution by flow cytometry. Exposure of ACBP resulted in increasing percentages of $\mathrm{G}_{0} / \mathrm{G}_{1}$ in BGC-823 cells (Table I, lower part). Persistent cell cycle arrest was also observed and optimal $\mathrm{G}_{0} / \mathrm{G}_{1}$ arrest $(68.8 \%)$ occurred when $20 \mu \mathrm{g} / \mathrm{ml}$ ACBP was added for $72 \mathrm{~h}$, whereas the corresponding values in the untreated control group was $52.6 \%$.

ACBP treatment increases $p 16^{\text {Ink4 }}, p 21^{\text {Wafl }}, p 2^{\text {Kipl }}$, bax and decreases cyclin D1, c-myc, bcl-2 mRNA expression. To evaluate the molecular mechanism regulated by ACBP, we analyzed a panel of important genes by semi-quantitative RT-PCR. The genes include tumor suppressor genes, such as $p 16^{\text {Ink4 }}, p 21^{\text {Wafl }}$, and $p 27^{\text {Kipl }}$; genes involved in apoptosis pathway, such as Bax and $B c l-2$; and genes controlling cell 
Table I. Effects of ACBP on cell cycle of BGC-823 (\%; mean \pm SD).

\begin{tabular}{|c|c|c|c|c|}
\hline BGC-823 & Group & $24 \mathrm{~h}$ & $48 \mathrm{~h}$ & $72 \mathrm{~h}$ \\
\hline Apoptosis & $\begin{array}{l}\text { Control } \\
\operatorname{ACBP}(5 \mu \mathrm{g} / \mathrm{ml}) \\
\operatorname{ACBP}(15 \mu \mathrm{g} / \mathrm{ml})\end{array}$ & $\begin{array}{l}0.36 \pm 0.015 \\
0.42 \pm 0.059^{\mathrm{a}} \\
0.53 \pm 0.067^{\mathrm{b}}\end{array}$ & $\begin{array}{l}0.40 \pm 0.055 \\
0.56 \pm 0.451^{\mathrm{a}} \\
0.59 \pm 0.153^{\mathrm{b}}\end{array}$ & \\
\hline Cell cycle & $\begin{array}{l}\text { Control } \\
\qquad \mathrm{G}_{0} / \mathrm{G}_{1} \\
\mathrm{~S} \\
\mathrm{G}_{2} / \mathrm{M} \\
\mathrm{ACBP}(20 \mu \mathrm{g} / \mathrm{ml}) \\
\mathrm{G}_{0} / \mathrm{G}_{1} \\
\mathrm{~S} \\
\mathrm{G}_{2} / \mathrm{M}\end{array}$ & $\begin{array}{c}66.4 \pm 19.2^{\mathrm{a}} \\
26.9 \pm 11.5^{\mathrm{a}} \\
7.1 \pm 8.2^{\mathrm{a}}\end{array}$ & $\begin{array}{c}65.9 \pm 7.1^{\mathrm{b}} \\
26.7 \pm 7.1^{\mathrm{b}} \\
7.3 \pm 0.6\end{array}$ & $\begin{array}{r}68.8 \pm 0.7^{\mathrm{b}} \\
26.1 \pm 1.3^{\mathrm{b}} \\
5.0 \pm 0.9^{\mathrm{a}}\end{array}$ \\
\hline
\end{tabular}

${ }^{\mathrm{a}} \mathrm{p}<0.05 ;{ }^{\mathrm{b}} \mathrm{p}<0.01$
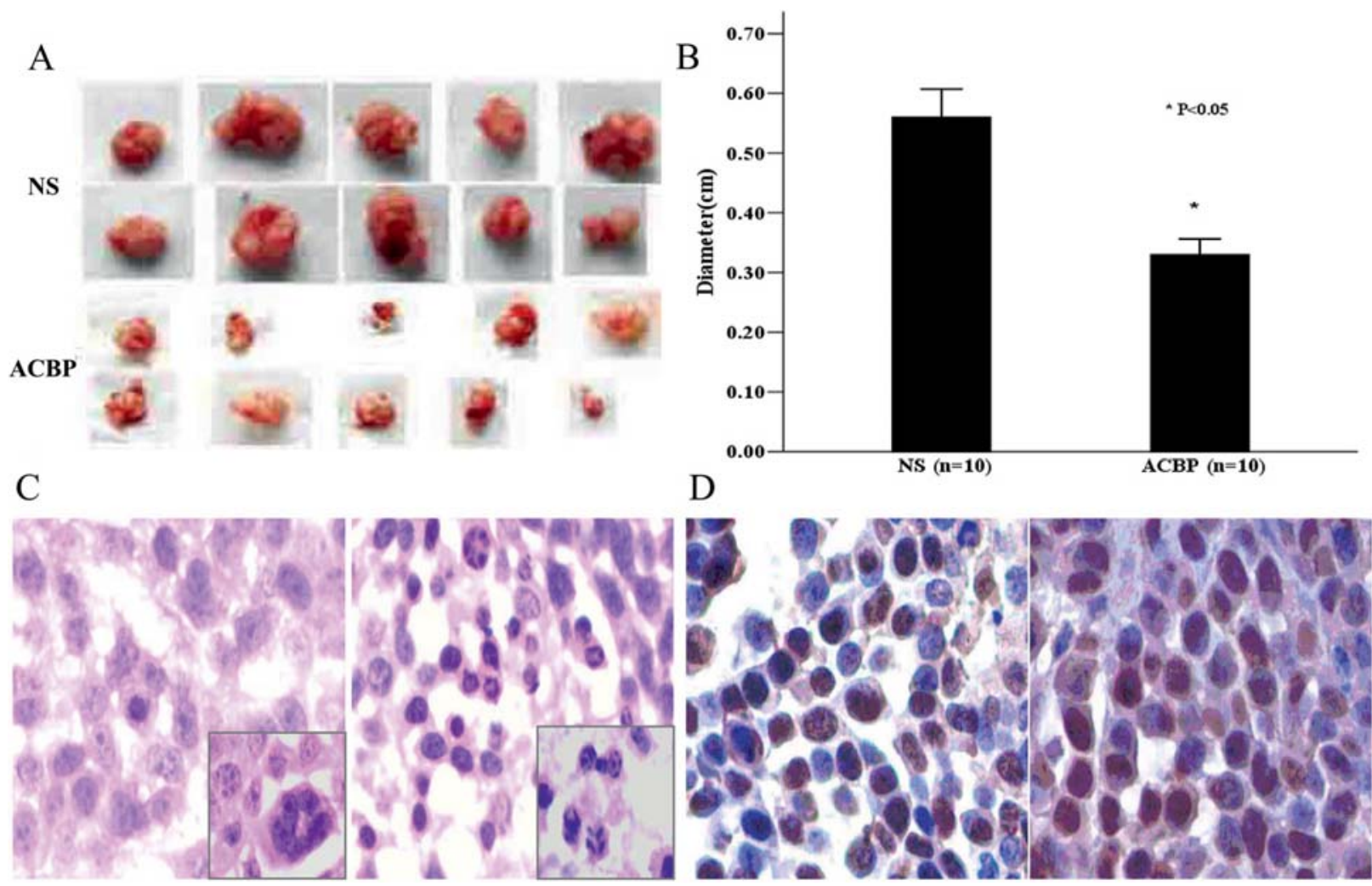

D

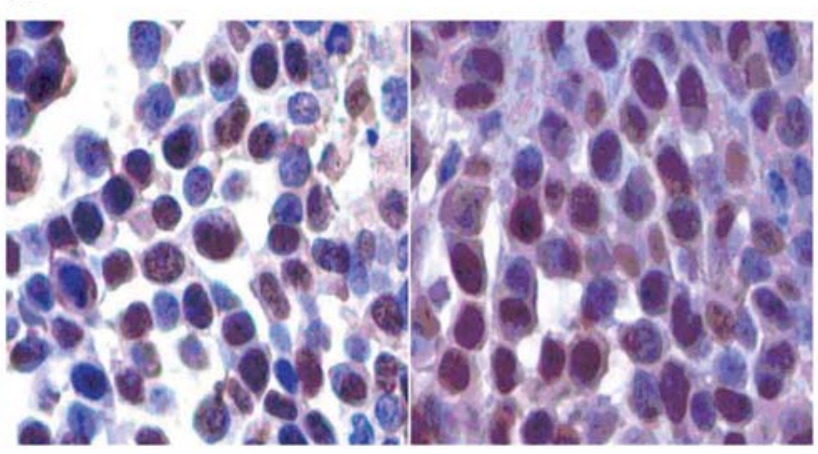

Figure 3. ACBP suppresses tumor growth in vivo. (A) Tumors were harvested after treated with ACBP (ACBP, $\mathrm{n}=10$ ) and compared with controls (NS, $\mathrm{n}=10)$. (B) Tumor size were measured, calculated and presented as mean \pm standard errors (SE). The statistical significance was observed $(\mathrm{p}=0.01)$. $(\mathrm{C})$ HE staining of tumor specimens harvested from in vivo experiments. More tumor cells with apoptotic features were detected in ACBP-treated group (right) when compared with control (left). (D) ACBP suppressed PCNA protein expression by IHC in tumors with ACBP treatment treated groups (right), when compared with control groups (left). The micrographs were take under light microscopy with x400 magnification.

cycle and proliferation, such as cyclin DI and c-myc (Fig. 2C). To test the gene expression, BGC-823 cells were treated with $20 \mu \mathrm{g} / \mathrm{ml} \mathrm{ACBP}$ for 24,48 and $72 \mathrm{~h}$, and compared with cells without treatment (B, blank controlled group) and cells treated with normal spleen peptide ( $\mathrm{N}$, negative control). Compared with cells treated with normal spleen peptide, $p 16^{\text {Ink } 4}$ expression was increased at 24 and $48 \mathrm{~h}$ after treat- ment and $p 21^{\text {Wafl }}$ expression was increased at $72 \mathrm{~h}$, while no significant change of $p 27^{K i p l}$ expression was observed. Decreased cyclin D1 was observed at 48 and $72 \mathrm{~h}$ after treatment, while decreased $c$-myc expression was observed only at $72 \mathrm{~h}$. Furthermore, the proapoptotic gene bax was increased at 48 and $72 \mathrm{~h}$, while the anti-apoptotic gene bcl-2 was decreased at $72 \mathrm{~h}$ after treatment (Fig. 2D). 
ACBP suppresses gastric tumor growth in a xenograft tumor model. The biological activity of ACBP was tested in a xenograft model in vivo with inoculation of gastric BGC-823 cancer cells. Compared with the controls, ACBP significantly suppressed tumor growth by $67 \%$ ( $\mathrm{p}=0.01$, Fig. $3 \mathrm{~A})$. The quality of life of tumor-bearing animals in the treated group was significantly improved over that of the control group. The mice in the treated group were more active, had good appetite, and their appearance and body weight were close to that of a normal mouse. Pathology analysis of harvested tumors showed more cells with apoptotic features in ACBP treated group (left, control group: 1.90 \pm 1.59 ; right, ACBP group: $4.19 \pm 2.02 ; p<0.001$, Fig. $3 C$ ). The proliferation index by immunostaining of PCNA of the tumor cells was significantly decreased in the treated group (left, control group: $38.87 \pm 1.98$; right, ACBP group: $49.72 \pm 1.82 \mathrm{p}<0.001$, Fig. 3D).

\section{Discussion}

In this study, we observed anticancer effect of ACBP through inhibition of the human gastric cancer cell line BGC-823 proliferation in vitro (Fig. 1B). The most potent effect reached $84.4 \%$ inhibitory rate, when treated with ACBP at the concentration of $25 \mu \mathrm{g} / \mathrm{ml}$ for $72 \mathrm{~h}$, which was concentration and time-dependent (Fig. 1B). The ACBPtreated cells exhibited typical morphological features of cell apoptosis when compared with typical cancer cell morphology of control cells under light microscope and electron microscope, suggesting that the anticancer effect of ACBP was due to induction of apoptosis (Fig. 2A and B). Quantitational analysis by flow cytometry of apoptosis further supported the observation (Table I). In addition, cell cycle analysis revealed that ACBP stopped BGC-823 cells at $\mathrm{G}_{0} / \mathrm{G}_{1}$ phase and decreased cells at $\mathrm{S}$ phase (Table I), indicating that ACBP might modulate the cell cycle checkpoints and block DNA synthesis.

The molecular mechanisms of ACBP induced apoptosis and cell cycle arrest were further assessed by gene expression controlling these biological activities. Oncogene $c$-myc, and genes involved in apoptotic process, $b c l-2$ and bax are critical molecules controlling gastric carcinogenesis, as well as many other solid tumors $(8,9)$. The increased expressions of $c-m y c$ and $b c l-2$, and the decreased expressions of bax are considered biomarkers of many cancers from epithelial origins, including gastric cancer (10-13). Li et al (14) reported that abnormal $c-m y c$ and $b c l-2$ expression are important factors in gastric carcinoma development; that overexpression of $c$-myc and $b c l$-2 corporately inhibit the apoptotic pathways. Decreased bax protein expression has been identified in the progress of various human malignant tumors (15-17). Our study is consistent with others that ACBP induces gastric cancer cell apoptosis through regulating the critical gene expression.

The anticancer effects of ACBP are also mediated through the modulation of gene expression involved in cell cycle regulatory proteins (cyclin D1,p16 $6^{\text {Ink } 4}, p 21^{\text {Wafl }}$, and $p 27^{\text {Kipl }}$, Fig. 2C and D). ACBP resulted in a significantly decreased expression of cyclin $D 1$ and a markedly increased expression of $p 16^{\text {Ink4 }}, p 21^{\text {Wafl }}$ and $p 27_{\text {Kipl }}$, that are important molecules modulating the universal process of cell dividing and participating in organism growth and development (18-20). Cell cycle progression is regulated by three functional classes of proteins, the cyclins, cyclin-dependent kinases (CDKs), and cyclin-dependent kinase inhibitors (CDKIs) $(21,22)$. These molecules play critical roles in DNA synthesis and cell division, that alterations in their function may lead to the disruption of normal cell growth and apoptosis, and subsequently, result in carcinogenesis (23). Thus, ACBP inhibition of cancer cell growth is achieved by downregulation of cyclin D (Fig. 2C and D). In addition, ACBP upregulated cell cycle inhibitors, such as p16 $6^{\text {Ink4 }}, \mathrm{p} 21^{\text {Waf1 }}$, and p2 $7^{\text {Kip1 }}$, which form cyclin-cdk complexes to regulate key checkpoints at the $G_{1} / S$ phase of cell cycle and control cell growth $(24,25)$. Furthermore, ACBP decreased cells in $\mathrm{S}$ phase and suppressed PCNA expression, which suggest that a decreased DNA synthesis might also be involved (Table I and Fig. 3D).

The potent anti-tumor growth activity of ACBP was observed in vivo, with consistent findings of in vitro study; that ACBP induced apoptosis and clock cell proliferation (Fig. 3). Our study suggests that the bioactive peptides with anticancer activity could be a novel strategy to develop therapeutic agents with low toxicity. There is a broad spectrum of bioactive peptides developed for targeting various diseases through different applications. For example, Artemisinin is a natural product isolated from Artemisia annua L. Oh et al reported that the artemisininpeptide conjugates showed potent anticancer activity against Molt-4 leukemia cells with a significantly improved cancer/normal cells selectivity (26). Pep42, a cyclic 13-mer oligopeptide that specifically binds to glucose-regulated protein 78 (GRP78) and internalizes into cancer cells, represents an excellent vehicle for tumor cell-specific chemotherapy (27). In addition, the non-immunogenicity of micro-peptides, especially of dipeptides and tripeptides, shows biological effects and ensures that consumers are free of anaphylaxis (28). Furthermore, peptide-based vaccines, one of several anti-tumor immunization strategies, can elicit both MHC Class I-restricted $\mathrm{CD}^{+}$and Class II-restricted CD4 ${ }^{+}$ cellular responses (29).

In conclusion, we showed in this study that ACBP potently inhibited gastric cell proliferation in vitro and suppressed tumor growth in vivo. ACBP induced cell apoptosis and blocked cell cycle through decrease of cyclin D1, c-myc, bcl-2 gene and PCNA protein expression, and increased $p 16^{\text {Ink4 }}, p 21^{\text {Wafl }}, p 27^{\text {Kipl }}$, and bax expression. Our preclinical study of ACBP suggests that ACBP modulates critical molecules controlling cell cycle and apoptosis, which could be developed as a new therapeutic approach against gastric neoplasms.

\section{Acknowledgements}

This study was supported by the National Natural Science Foundation of China (No. 30860327, China), Major Project of Inner Mongolia Medical College (No. ZD9809, China), and NIH/NIDCD intramural research projects Z01-DC000016 (USA). We thank Dr Ke Yang (Beijing University Medical Health Center) for helpful discussions and for providing cells lines. We also thank Cindy Clark (NIH library) for helpful revision of the manuscript. 


\section{References}

1. Parkin DM, Bray F, Ferlay J and Pisani P: Global cancer statistics, 2002. CA Cancer J Clin 55: 74-108, 2005.

2. Sun XD, Mu R, Zhou YS, et al: Analysis of mortality rate of stomach cancer and its trend in twenty years in China. Zhonghua Zhong Liu Za Zhi 26: 4-9, 2004.

3. Su XL, Ke Y, Yan MR, Chen CH, Qing P and Ying S: The experimental research on anti-gastric cancer active peptide. Int J Moden Cancer Ther 2: 26-27, 1999.

4. Hou JF, Yan MR, Rong YN, Jiao TM and Su XL: Effect of anticancer bioactive peptide on leukemia mice. Acta Academiae Med Neimongol 26: 3-6, 2004.

5. Zhao YY, Peng SD and Su XL: Effects of anti-cancer bioactive peptide on cell cycle in human nasopharyngeal carcinoma strain CNE. Zhonghua Er Bi Yan Hou Tou Jing Wai Ke Za Zhi 41: 607-611, 2006.

6. Yan MR, Su XL and Liu QP: Effect of anti-gastric cancer biological peptide on lactic dehydrogenase isoenzyme. China J Cancer Prev Treat 9: 382-383, 2002.

7. Quan XH and Xiu LS: Effect of anti-gastric cancer biological peptide on mice and induction of TNF. Chin J Cancer Biother 12: 301-302, 2005.

8. Kountouras J, Zavos C and Chatzopoulos D: New concepts of molecular biology on gastric carcinogenesis. Hepatogastroenterology 52: 1305-1312, 2005.

9. Milne AN, Sitarz R, Carvalho R, Carneiro F and Offerhaus GJ: Early onset gastric cancer: on the road to unraveling gastric carcinogenesis. Curr Mol Med 7: 15-28, 2007.

10. Sumi T, Tsuneyoshi N, Nakatsuji N and Suemori H: Apoptosis and differentiation of human embryonic stem cells induced by sustained activation of c-Myc. Oncogene 26: 5564-5576, 2007.

11. Arnoult D: Apoptosis-associated mitochondrial outer membrane permeabilization assays. Methods 44: 229-234, 2008.

12. Nemec KN and Khaled AR: Therapeutic modulation of apoptosis: targeting the BCL-2 family at the interface of the mitochondrial membrane. Yonsei Med J 49: 689-697, 2008.

13. Xiang TX, Li Y, Jiang Z, et al: RNA interference-mediated silencing of the Hsp70 gene inhibits human gastric cancer cell growth and induces apoptosis in vitro and in vivo. Tumori 94 539-550, 2008

14. Li XL, Hao YR, Zou JX, Yang JH and Geng JH: Relationship between $\mathrm{C}$-myc and Bcl-2 alterations and biological behavior and apoptosis in gastric cancer. Xin Xiaohuabingxue Zazhi 5: 773-774, 1997.
15. Kato K, Kawashiri S, Yoshizawa K, Kitahara H and Yamamoto E: Apoptosis-associated markers and clinical outcome in human oral squamous cell carcinomas. J Oral Pathol Med 37: 364-371, 2008.

16. Lima MA, Ferreira MV, Barros MA, et al: Relationship between EBV infection and expression of cellular proteins c-Myc, Bcl-2, and Bax in gastric carcinomas. Diagn Mol Pathol 17: 82-89, 2008

17. Liu FS, Jan YJ, Lai CR, et al: Expression analysis of apoptosisrelated markers TP53, BCL-2, BAX and c-MYC in female genital tract sarcomas. J Chin Med Assoc 71: 628-634, 2008.

18. Cheng T: Cell cycle inhibitors in normal and tumor stem cells. Oncogene 23: 7256-7266, 2004.

19. Coffman JA: Cell cycle development. Dev Cell 6: 321-327, 2004.

20. Grzelakowska-Sztabert B: Cell cycle checkpoints, molecular background. Folia Morphol (Warsz) 63: 1-3, 2004.

21. Lukas J, Lukas C and Bartek J: Mammalian cell cycle checkpoints: signalling pathways and their organization in space and time. DNA Repair (Amst) 3: 997-1007, 2004.

22. Murray AW: Recycling the cell cycle: cyclins revisited. Cell 116: 221-234, 2004

23. Johansson M and Persson JL: Cancer therapy: targeting cell cycle regulators. Anticancer Agents Med Chem 8: 723-731, 2008.

24. Sherr CJ: Mammalian G1 cyclins and cell cycle progression. Proc Assoc Am Physicians 107: 181-186, 1995.

25. Sherr CJ: The Pezcoller lecture: cancer cell cycles revisited. Cancer Res 60: 3689-3695, 2000.

26. Oh S, Kim BJ, Singh NP, Lai H and Sasaki T: Synthesis and anti-cancer activity of covalent conjugates of artemisinin and a transferrin-receptor targeting peptide. Cancer Lett 274: 33-39, 2009.

27. Yoneda Y, Steiniger SCJ, Capkova K, et al: A cell-penetrating peptidic GRP78 ligand for tumor cell-specific prodrug therapy. Bioorgan Medicin Chem Lett 18: 1632-1636, 2008.

28. Sarkar C, Singh SK, Mandal SK, et al: Human placental protein/ peptides stimulate melanin synthesis by enhancing tyrosinase gene expression. Mol Cell Biochem 285: 133-142, 2006.

29. Mirshahidi S, Kramer VG, Whitney JB, et al: Overlapping synthetic peptides encoding TPD52 as breast cancer vaccine in mice: prolonged survival. Vaccine 27: 1825-1833, 2009. 